\title{
Arthropod diversity sheltered in Thaumetopoea pityocampa (Lepidoptera: Notodontidae) larval nests
}

\author{
MANUELA BRANCO, ${ }^{1}$ MÁRCIA SANTOS, ${ }^{2}$ TERESA CALVÃO ${ }^{2}$ \\ GILLIA N TELFER ${ }^{3}$ and MARIA-ROSA PA IVA ${ }^{2}{ }^{1}$ Centro de Estudos Florestais, Instituto \\ Superior de Agronomia, Technical University of Lisbon, Lisboa, Portugal, ${ }^{2}$ DCEA, Faculdade de Ciências e Tecnologia, Universidade \\ Nova de Lisboa, Campus de Caparica, Caparica, Portugal, ${ }^{3}$ Centro de Ecologia Aplicada 'Prof. Baeta Neves', Instituto Superior de \\ Agronomia, Technical University of Lisbon, Lisboa, Portugal
}

\begin{abstract}
In pine ecosystems, the role of the larval nests of the Mediterranean defoliator Thaumetopoea pityocampa as shelter of other arthropods, was studied for the first time. In Portugal, Pinus stands which differed in understorey plant diversity and level of attack by $T$. pityocampa were compared.

2. The arthropod fauna found sheltering inside the nests consisted of 60 species, representing 12 foraging types. Both arthropod richness and abundance were positively correlated with nest size, expressed as larval biomass. Arthropod richness was further positively correlated with understorey plant diversity, while no correlation was detected between arthropod richness and nest density.

3. Spiders accounted for up to $50 \%$ of the species richness, while $80 \%$ of the individuals collected were either juveniles, or females with brood, implying that $T$. pityocampa nests are used for overwintering and brood care. Seventy-six per cent of the Araneae were nocturnal ground foragers and specialised cryptic hunters, demonstrating the occurrence of indirect interactions among species belonging to different communities, namely ground vegetation layers and forest pine coppice.

4. It was concluded that, in Mediterranean pine ecosystems, T. pityocampa nests (i) create habitat diversification and contribute to improve overwintering survival of a wide range of arthropod species; (ii) play a functional role in the food web of pine ecosystems, by promoting indirectly mediated interactions among species from different communities; and (iii) do not contribute to create habitat for symtopic phytophagous arthropods, since contrary to literature references for different types of shelters, $98 \%$ of the associated species belonged to foraging types other than T. pityocampa.
\end{abstract}

Key words. Araneae, arthropod diversity, larval nests, pines, Thaumetopoea pityocampa, understorey diversity.

\section{Introduction}

The pine processionary moth, Thaumetopoea pityocampa Denis \& Schiffer is a defoliator attaining ecological and economic importance across the Mediterranean region. The larvae are social and feed communally upon the needles located in the vicinity of the maternal egg-batch, around which they spin silk nests. Development takes place throughout the winter

Correspondence: Manuela Branco, Centro de Estudos Florestais, Instituto Superior de Agronomia, Technical University of Lisbon, 1349017 Lisboa, Portugal. E-mail: mrbranco@isa.utl.pt

(C) 2008 The Authors

Journal compilation @ 2008 The Royal Entomological Society and larvae from different batches sometimes merge, nest size being positively correlated with larval growth and survival (Pérez-Contreras et al., 2003). Nests are believed to afford protection against predation, parasitism and adverse weather conditions, while improving larval thermoregulation and nest temperatures (e.g. Breuer \& Devkota, 1990). Additionally, they may enclose food sources to the advantage of the primary shelter maker, co-existing organisms and secondary users (e.g. Fukui, 2001). In pine stands, nest densities of over 200 nests $\mathrm{ha}^{-1}$ may be attained, thus pointing to the role of $T$. pityocampa as ecosystem engineer, that is in creating habitat (Jones et al., 1994, 1997). 
Social larval behaviour is a rare ecological strategy among lepidopterous species (Costa \& Pierce, 1997), apparently associated with outbreak traits (Hunter, 1991). Although the role of leaf shelters in fostering interactions within, and among trophic levels has been documented (e.g. Cappuccino, 1993; Cappuccino \& Martin, 1994; Kudo, 1994; Larsson et al., 1997; Martinsen et al., 2000; Lill \& Marquis, 2004), similar studies of communal tents, built by gregarious, or social lifestyle Lepidoptera larvae, were seldom conducted and mainly focused on natural enemies (e.g. Arevalo, 1992), while disregarding other arthropod nest inquilines.

Indirect interactions among species (Schmitz \& Suttle (2001) are important drivers shaping community assemblage and functioning (e.g. Werner \& Peacor, 2003). Most studies focus on interactions mediated by plant trait responses and habitat alterations which affect community dynamics (e.g. Cappuccino \& Martin, 1994; Jones et al., 1997; Martinsen et al., 2000; Werner and Peacor, 2003). However, within communities the role of inter-specific interactions, indirectly mediated by other species (e.g. Bolker et al., 2003; Ohgushi, 2005) is still poorly documented.

The present work aimed at establishing if $T$. pityocampa communal tents might also benefit the associated symtopic arthropod fauna, as observed for leaf shelter builders (e.g. Fukui, 2001). Furthermore, if the abundance and diversity of arthropods, establishing interactions with $T$. pityocampa nests, would be a function of (i) understorey plant diversity, assuming that arthropod diversity increases with plant diversity (e.g. Altieri, 1999); (ii) nest density, that is, number of nests per area; and/ or (iii) nest size, expressed as larval biomass. The topics studied have not been addressed before.

\section{Material and methods}

\section{Stand location, larval nest sampling and nest density}

Ten to 15 winter nests of $T$. pityocampa were randomly collected from each one of four pine stands (Table 1), at monthly intervals between October and March 1999-2000, in order to cover the period of T. pityocampa larval development from L2 to L5. Ten additional nests were further collected in late March, after nest abandonment by the larvae. Nest density per hectare was determined by counting the number of nests per tree, and either the number of trees in plots of $50 \times 50 \mathrm{~m}$, or if not possible, those falling inside three transects of $50 \times 3 \mathrm{~m}$ each.

\section{Understorey diversity}

Plant diversity and species composition were studied by setting up two to four line transects, $20 \mathrm{~m}$ long each, separated from the nearest one by $20 \mathrm{~m}$, by placing a measuring tape straight over the vegetation. All plants were identified to species, and the length of the canopy intersected by the tape was measured. The length of the bare ground intersected by the tape was also recorded. Plant diversity was estimated by applying the Shannon Index, using both the number of individuals and the percentage cover of the different species, recorded along the line.

\section{Larval density, biomass and nest size}

Nest volume was determined by measuring the three main axes of 15 to 18 nests in total, sampled at the peak of the L2, L3 and L4/L5 larval stages. Larval biomass was determined by sampling 10 to15 larvae of each instar, randomly collected from different nests, in each stand. Dry larval weight was determined after $48 \mathrm{~h}$ drying. Nest biomass was determined by multiplying the number of larvae at each instar by the respective mean larval dry weight.

\section{Arthropod identifications}

The nests collected were opened in the laboratory, thus implying destruction, where all arthropods were counted and identified to either family, genus or species, or to operational taxonomic units, OTUs (Sneath \& Sokal, 1973). Immature stages were separated and placed in rearing chambers to complete development. The following foraging types were individually assigned to nest dwelling arthropods: parasitoids, predators, omnivorous, fungi feeders, necrophagous and phytophagous. Aranea were further subdivided into seven types: jumping hunters, nocturnal foragers, cryptic hunters, scattered line weavers, orb builders, sheet weavers, diurnal hunters (e.g. Marc et al., 1999; Uetz et al., 1999). Their stage of development was also recorded, to allow for the establishement of trophic relationships.

\section{Diversity indices and statistical treatments}

Species richness $(s)$ was defined as the total number of arthropod species per nest and stand. The mean number of arthropods

Table 1. Characterisation of the Pinus pinaster Ait. stands studied, Portugal.

\begin{tabular}{llclll}
\hline & $\begin{array}{l}\text { Coordinates (N; }) \\
\text { Stand }\end{array}$ & $\begin{array}{l}\text { Number } \\
\text { nests ha }{ }^{-1}\end{array}$ & $\begin{array}{l}\text { Sampled } \\
\text { nests }\end{array}$ & & \multicolumn{2}{l}{ Understorey plant species diversity } \\
\cline { 5 - 6 } & $39^{\circ} 50^{\prime} \mathrm{N}, 8^{\circ} 57^{\prime} \mathrm{W} ; 50 \mathrm{~m}$ & $55 \dagger$ & 203 & 0.97 & 6.5 \\
Leiria & $39^{\circ} 30^{\prime} \mathrm{N}, 9^{\circ} 11^{\prime} \mathrm{W} ; 35 \mathrm{~m}$ & $110 \dagger$ & 157 & 1.23 & 5.5 \\
Apostiça & $39^{\circ} 26^{\prime} \mathrm{N}, 8^{\circ} 04^{\prime} \mathrm{W} ; 160 \mathrm{~m}$ & $38 \dagger$ & 131 & 0.33 & 1.5 \\
Pucariça & $39^{\circ} 32^{\prime} \mathrm{N}, 8^{\circ} 15^{\prime} \mathrm{W} ; 230 \mathrm{~m}$ & $397 \dagger$ & 160 & 0.43 & 2.0 \\
Barrada & &
\end{tabular}

$\dagger$ Monoculture, even aged, approximately 10-15 years old. $\ddagger$ natural regeneration, mixed with low numbers of Pinus pinea L. and Quercus suber L. 
Table 2. Number and percentage of arthropods from different taxa, found sheltering inside Thaumetopoea pytiocampa nests and respective feeding groups. Portugal, 1999-2000.

\begin{tabular}{|c|c|c|c|}
\hline Class/Order & Family/Species & Total and (percentage) & Foraging types \\
\hline \multirow[t]{11}{*}{ Araneae } & & $263(9.74)$ & Predators \\
\hline & Salticidae & 57 & Jumping hunter \\
\hline & Clubionidae & 112 & Nocturnal forager \\
\hline & Gnaphosidae & 18 & Nocturnal forager \\
\hline & Thomisidae & 20 & Cryptic hunters \\
\hline & Philodromidae & 27 & Cryptic hunters \\
\hline & Theridiidae & 1 & Scattered line weavers \\
\hline & Araneidae & 1 & Orb builders \\
\hline & Linyphiidae & 1 & Sheet weavers \\
\hline & Liocraniidae & 13 & Diurnal hunter \\
\hline & Unidentifiable & 13 & \\
\hline Chilopoda & & $3(0.11)$ & Predators \\
\hline Diplopoda & Julidae & $67(2.48)$ & Omnivorous \\
\hline Blattoidea & Polyphagidae & $1(0.04)$ & Omnivorous \\
\hline Collembola & Entomobryidae & $18(0.67)$ & Omnivorous \\
\hline \multirow[t]{7}{*}{ Coleoptera } & Coccinelidae & $5(0.19)$ & Predators \\
\hline & Cryptophagidae Micrambe perrisi Brisout & $723(26.77)$ & Fungi feeders \\
\hline & Curculionidae & $5(0.19)$ & Phytophagous \\
\hline & Dermestidae Dermestes aurichalceus Küster & $12(0.44)$ & Necrophagous \\
\hline & Scolytidae Tomicus sp. & $1(0.04)$ & Phytophagous \\
\hline & Staphilinidae & $4(0.15)$ & Omnivorous \\
\hline & Other & $14(0.52)$ & $?$ \\
\hline Dermaptera & Forficulidae Forficula $s p$ & $55(2.04)$ & Omnivorous \\
\hline \multirow[t]{4}{*}{ Diptera } & Mycetophilidae & $2(0.07)$ & Fungi feeder \\
\hline & Phoridae & $19 \dagger(0.70)$ & Necrophagous \\
\hline & Tachinidae Phryxe caudata Rond. & $1147(42.47)$ & $\begin{array}{l}\text { Parasitoid of } \\
\text { Thaumetopoea pityocampa }\end{array}$ \\
\hline & Syrphidae Xanthandrus comtus Harr. & $9(0.33)$ & Predators \\
\hline \multirow[t]{5}{*}{ Hemiptera } & Aphididae (Lachninae) Cinara sp. & $21(0.78)$ & Phytophagous \\
\hline & Anthocoridae & $1(0.04)$ & Predators \\
\hline & Cercopidae & $5(0.19)$ & Phytophagous \\
\hline & Cixiidae & $3(0.11)$ & Phytophagous \\
\hline & Lygaeidae & $1(0.04)$ & Phytophagous \\
\hline \multirow[t]{11}{*}{ Hymenoptera } & Formicidae & $13(0.48)$ & \\
\hline & Crematogaster scutellaris Olivier & 1 & Predators \\
\hline & Formica fusca Vikberg & 1 & Predators \\
\hline & Lasius sp & 5 & Predators \\
\hline & Lasius emarginatus Laus. & 6 & Predators \\
\hline & Braconidae Meteorus versicolor Wesma & $27(1.00)$ & Parasitoid of T. pityocampa \\
\hline & Braconidae Orthostigma sp. & $7 \dagger(0.26)$ & Parasitoids of Phoridae \\
\hline & Ichneumonidae Erigorgus femorator Aubert & $6(0.22)$ & Parasitoid of T. pityocampa \\
\hline & Ichneumonidae (Diplazontinae) & $3 \ddagger(0.11)$ & Parasitoids of Syrphidae \\
\hline & Pteromalidae Dybrachis cavus Walk. & $212 \S(7.85)$ & Parasitoid of $P$. caudata \\
\hline & Pteromalidae Habrocytes sp. & $50 \S(1.85)$ & Parasitoid of $P$. caudata \\
\hline Lepidoptera & Unidentified larvae & $4(0.15)$ & Phytophagous \\
\hline
\end{tabular}

$\dagger$ Collected in March from nests with many dead larvae; †emerged from pupae of Xanthandrus comtus (Syrphidae); §emerged from pupae of Phryxe caudata.

sheltered per nest was also calculated. Species richness and the mean number of arthropods per nest among stands were compared using a Kruskall-Wallis H test, followed by a MannWhitney $U$ test, to detect differences between pairs of stands. Spearman's correlation coefficient $\left(r_{\mathrm{s}}\right)$ was used to detect variable association.

\section{Results}

\section{Patterns of diversity and abundance}

A highly diverse arthropod fauna, approximately 60 species of 36 families, representing 12 foraging types, was found in $T$.

(C) 2008 The Authors

Journal compilation (C) 2008 The Royal Entomological Society, Insect Conservation and Diversity, 1, 215-221 
pityocampa nests (Table 2). The taxa of the arthropods sheltered in the nests varied seasonally. Omnivorous, predators and fungi feeders were present in higher numbers between October and December, whereas from January to March parasitoids made up the largest percentage (Fig. 1). Arthropods remaining in abandoned nests (Fig. 2) consisted mainly of the parasitoid Phryxe caudata Rond. (20-60\%), omnivorous millipedes and Dermaptera (10$30 \%$ ), and arachnids (10-50\%).

Spiders accounted for $10 \%$ of all arthropods collected, representing 9 families and 11 genera (Table 2). The families Clubionidae (genera Clubiona and Cheiracanthium), Salticidae, Thomisidae (Synaema sp.), and Gnaphosidae, (genus Aphantaulax) were the most abundant, accounting respectively for $44 \%$, $22 \%, 8 \%$ and $7 \%$ of all specimens. Spiders were found as early as October inside L2 nests and their abundance increased with nest size, until March. Empty nests collected in March were still inhabited by individuals of the genera Clubiona, Synaema and Aphantaulax. Broods of arachnids including adults with egg sac, or juveniles, were found in higher numbers than adults, consequently dominating the arachnid collection (71\%). Hunting

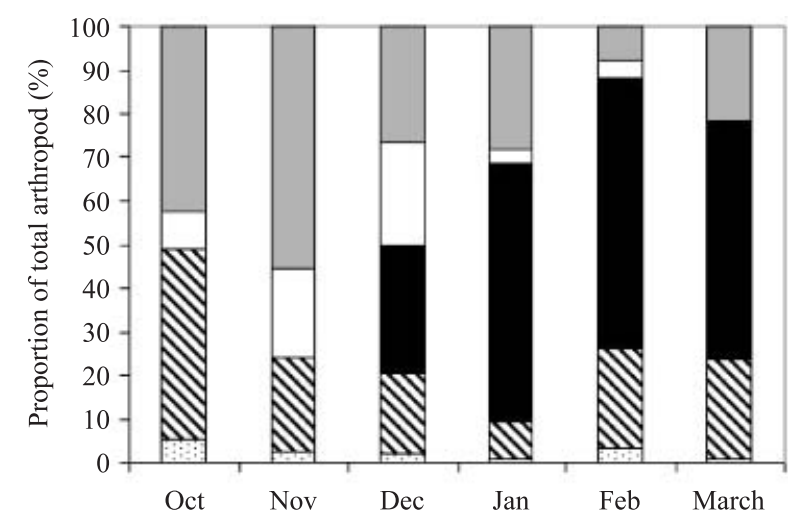

曰phytophagous $\mathbf{\nabla}$ predators $\mathbf{a}$ parasitoids $\square$ fungifeeders $\square$ omnivorous

Fig. 1. Variation throughout the winter of the proportions of arthropods belonging to different foraging types, in relation to the total observed in four stands. Portugal, 1999-2000.

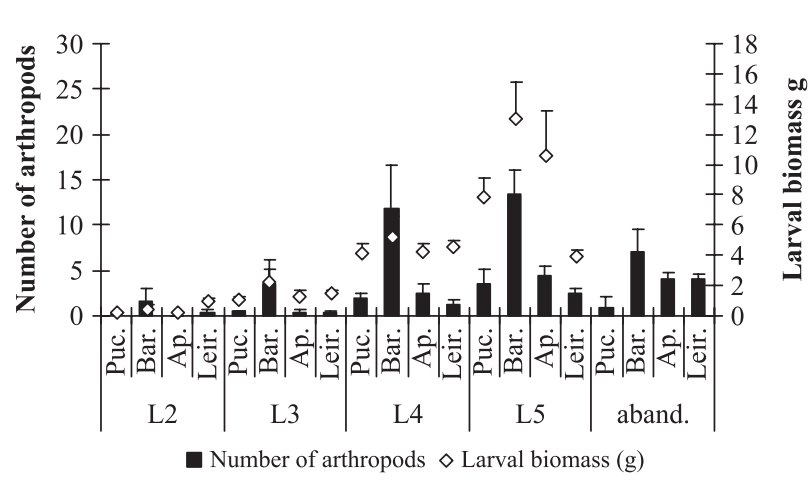

Fig. 2. Thaumetopoea pityocampa larval biomass ( $\mathrm{g}$ of dry weight) per nest $(\overline{\mathrm{X}}+\mathrm{SE})$ (open diamonds) and number of arthropods per nest, for each stand $(\overline{\mathrm{X}} \pm \mathrm{SE})$ (dark bars). Portugal, 1999-2000. spiders, including jumping spiders (23\%), nocturnal foragers $(56 \%)$ and specialised cryptic hunters $(19 \%)$ were the most common foraging types, by contrast with web-building spiders, which reached less than $3 \%$ of the total.

Parasitoids represented $44 \%$ of the arthropods and were only present from the fourth $T$. pityocampa larval instar onwards. According to location and year, between $75-98 \%$ of the specimens were collected either as late larvae, or pupae, which later developed into adults in the laboratory. Apart from P. caudata, two other T. pityocampa parasitoids, Meteorus versicolor Wesma and Erigorgus femorator Aubert, were found in lower numbers, while a few species and individuals of Phoridae and Syrphidae, were mostly collected as pupae. The hyperparasitoids Dybrachis cavus Walk. and Habrocytus sp. emerged in high numbers, parasitising $3 \%$ to $16 \%$ of the $P$. caudata pupae.

Insect predators were seldom found, consisting of nine syrphyds, Xanthandrus comtus Harr., mostly in the pupal stage, 13 ants, five coccinelids and one anthocorid. Fungi feeders, Micrambe perrisi Brisout (Coleoptera, Cryptophagidae), were common in November and December and constituted $27 \%$ of the arthropods.

Omnivorous and necrophagous arthropods represented $7 \%$ of the total and were often found in recently abandoned nests. This foraging type was dominated by two species, one forficulid (Dermaptera) and a millipede of the family Julidae (Diplopoda). The dermestid Dermestes aurichalceus Küester is a probable scavenger of T. pityocampa dead larvae (Herrmann \& Bahillo de la Puebla, 2003). In total herbivores, mainly phloem feeders such as Cinara sp. and Cercopidae, accounted for only $1.4 \%$ of the arthropods collected.

From the end of the first until the fifth instar, individual larval dry weight increased by a factor of about 1000 . Consequently, mean density of larvae per nest decreased and nest larval biomass followed an increasing trend, from L2 to L5 (Figs 2 and 3). Concomitantly, nest volume $(\bar{x} \pm \mathrm{SE})$ increased from $9.3 \mathrm{~cm}^{3} \pm 1.16$, $(n=15)$ in mid-October (L2), to $104.4 \mathrm{~cm}^{3} \pm 11.03(n=18)$ at the end November (L3), and finally to $404.4 \mathrm{~cm}^{3} \pm 11.03(n=18)$ in February, when all larvae had completed development. The number of larvae per nest decreased between October and November, due to the mortality occurring in the L1 and L2 instars

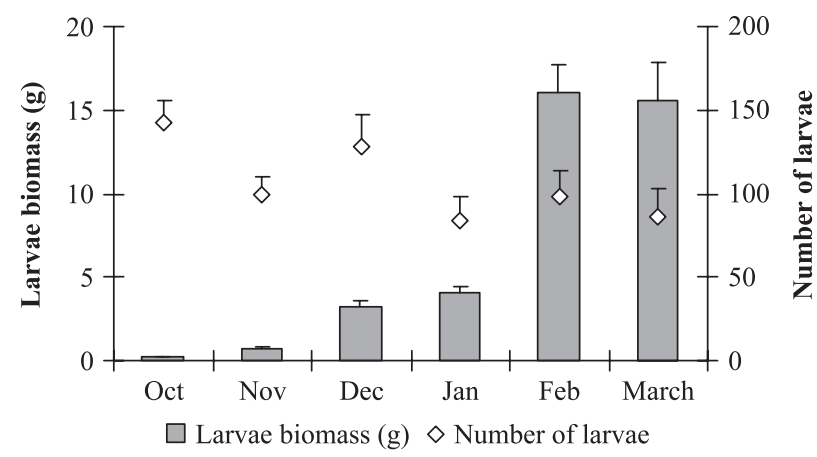

Fig. 3. Thaumetopoea pityocampa larval density and biomass per nest $(\overline{\mathrm{X}}+\mathrm{SE})$ throughout the period of larval development, from October (L2) to March (L5), data pooled for all stands, considering the nests occupied with live larvae. Portugal, 1999-2000. 
(Pérez-Contreras et al., 2003), followed by an increase in December, resulting from group merging, a trend which was particularly noticeable in Apostiça and Barrada (Fig. 3). In stands having a high density of nests per tree, several colonies can merge so that one nest may contain up to 1334 larvae, as observed in Barrada. As from January onwards, high numbers of dead larvae were found in L4/L5 nests. In March, larvae descended to the ground for pupation and most nests contained only dead larvae, if any.

\section{Association patterns at nest and stand level}

At nest level, both the abundance and richness of arthropods per occupied nest, were positively related to mean larval biomass $\left(r_{\mathrm{s}}=0.97 ; n=562, P<0.001\right.$ and $r_{\mathrm{s}}=0.97 ; n=562, P<0.001$, respectively). The number of nest-associated arthropods increased throughout the winter, following nest size and total larval biomass (Fig. 2), attaining a factor as high as 22, between instars L2 and L5. Larval biomass also varied significantly among stands $\chi^{2}=13.3$ (d.f. $=3, P=0.004$ ). In addition, the mean number of arthropods per nest was seven times higher in the stand with the largest larval biomass per nest, Barrada, than in the stand with the smallest one, Leiria.

A significant positive correlation was further encountered between the number of arthropods per nest, and spider richness $\left(r_{\mathrm{s}}=0.75, n=351, P<0.001\right)$.

At stand level, arthropod species richness per nest, differed significantly according to stand, $\chi^{2}=24.25$ (d.f. $=3, P<0.001$ ). Furthermore, a significant positive correlation was detected between the mean richness of arthropods per nest, and understorey plant diversity $\left(r_{\mathrm{s}}=1.00, n=4, P<0.001\right)$. In Apostiça a significantly higher mean number of species per nest was found, than in Barrada, Leiria and Pucariça, $Z=-2.06, P=0.039$, $Z=-2.33, P=0.020$ and $Z=-5.05, P<0.001$, respectively (Fig. 4), with Leiria and Barrada having similar values $(Z=-0.23$, $P=0.817)$. In contrast, no significant correlation was found between the number of nests per hectare, and arthropod richness $\left(r_{\mathrm{s}}=0.40, n=4, P=0.60\right)$. However, nest density was positively correlated with the mean number of arthropods per nest $\left(r_{\mathrm{s}}=1.00\right.$,

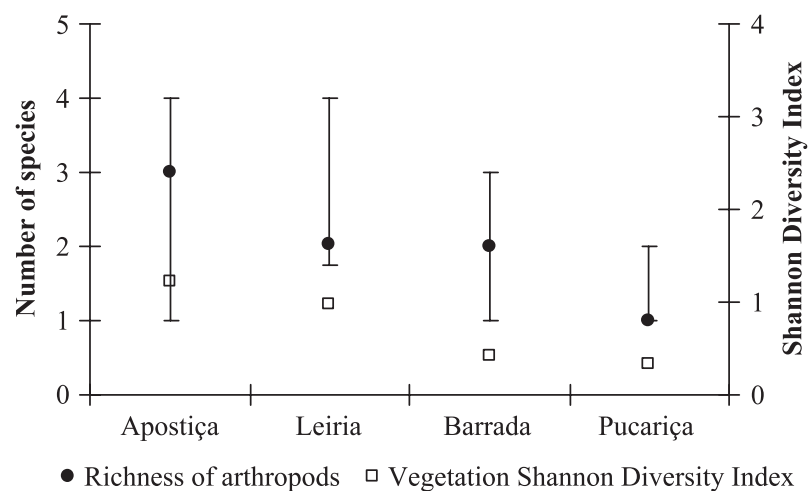

Fig. 4. Richness of arthropods per nest, median (black circles) and inter-quartile range (line), and Shannon Diversity Index for the vegetation (open squares). Portugal 1999-2000. $n=4, P<0.001$ ), a result mainly due to the high numbers of the parasitoid $P$. caudata.

Spider abundance also differed significantly according to stand, $\chi^{2}=16.3$ (d.f. $=3, P=0.001$ ). The average number of spiders per nest $( \pm S E)$ was higher in Leiria $(1.14 \pm 0.01)$, followed by Apostiça (0.76 \pm 0.09$)$, Barrada $(0.50 \pm 0.03)$ and Pucariça $(0.21 \pm 0.09)$. Araneae represented approximately $49 \%$ of the total species richness in the two stands having the highest understorey diversity, Leiria and Apostiça, 33\% in Pucariça, and 28\% in Barrada.

\section{Discussion}

The rich and abundant arthropod fauna sheltered inside $T$. pityocampa nests was studied in detail, for the first time. Most of the $\mathrm{ca}$. 60 species identified, representing 12 foraging types, belonged to trophic levels other than $T$. pityocampa, while phytophagous arthropods accounted for $1.4 \%$ of the total only. It can thus be inferred that $T$. pityocampa nests promote interactions among trophic levels, a finding which is innovative. On the other hand, contrary to observations for leaf rollers (Cappucino, 1993; Cappucino \& Martin, 1994), nests did not contribute to foster interactions among phytophagous species.

Although the number of stands sampled was small, arthropod species richness was significantly higher in pine stands having higher vegetation diversity, regarding both stand composition and understorey vegetation, than in young monocultural plantations with scarce understorey. These findings are in accordance with predictions which couple variations of the diversity of plant and arthropod communities, regarding both herbivores and higher trophic levels (e.g. Siemann, 1998). They further agree with Santos et al. (2002), who detected significant positive correlations between understorey species richness of pine stands in Portugal and Hymenoptera diversity.

Araneae heavily influenced the overall abundance and diversity of $T$. pityocampa nest-associated arthropods, leading us to conclude that (i) spiders use nests for brood care, since $80 \%$ of the individuals collected were juveniles, or females with egg sacs; (ii) $99 \%$ of the spiders were non-web builders, including jumping hunters (Salticidae), cryptic hunters, (Thomisidade, and Philodromidae), and nocturnal ground foragers (Clubionidade and Gnaphosidae); (iii) the two later groups accounted for $75 \%$ of the spiders collected, providing evidence of the occurrence of an interaction between communities of the pine coppice, and of the ground vegetation layers, similarly to suggested for other agroecosystems (e.g. Bogya \& Markó, 1999); and (iv) nests are extensively used by Araneae, even after larval abandonment. In general, communal tents protect from climatic elements and facilitate the accumulation of thermal energy during the winter (e.g. Bryant et al., 2000; Ruf \& Fiedler, 2000; Ruf \& Fiedler, 2002).

Our results show that $T$. pityocampa nests provide shelter and habitat for non-web-builder spiders, by supplying a microclimate suitable for arachnid juvenile development, a novel finding. Previous authors have shown that adult Clubionids occur both on the ground and canopy throughout the summer (e.g. Bogya et al., 2000). It can thus be inferred that nests contribute to improve the survival of large numbers of spiders. 
Throughout the season, larval biomass was positively correlated with arthropod abundance and diversity, demonstrating the importance of nest size regarding the number of interactions established.

By the end of the winter, peak larval biomass was attained and a large amount of faeces, exuviae, fungi and dead arthropods were accumulated inside the nests. This substantial food resource attracted decomposers, scavengers and fungi feeders, such as Micrambe perrisii (Coleoptera, Cryptophagidae), which also inhabits nests of Thaumetopoea pinivora L., while a sympatric species, Micrambe umbripennis Reitter, associates with different caterpillar species (Reska, 1994; Otero, 2001). Observations thus appear to indicate a co-evolutionary nature for the relationship established between social caterpillars and nest cleaning arthropods.

Although this study did not aim at studying host-parasitoid density relationships, a positive correlation was found between T. pityocampa nest density and its main larval parasitoid, $P$. caudata (e.g. Triggiani et al. 1993). The apparent direct density-dependent relationship detected is probably justified by the fact that $P$. caudata is a specialist parasitoid of T. pityocampa, as confirmed by, for example, Biliotti (1958).

By contrast, few generalist predators and parasitoids, such as $M$. versicolor were present, which agrees with the theory relating the effectiveness of shelter protection with the level of natural enemy specialisation (e.g. Jones et al., 2002; Weiss et al., 2004). Since hyperparasitoids and parasitoids of Phoridae and Syrphidae were also collected, we postulate that $T$. pityocampa nests are involved in multiple links of the pine ecosystem food web.

Since over two-thirds of the parasitoid specimens were sampled in late larval, or pupal stages, and considering that adult parasitoids and predators remain inside the nests for shorter periods than immature stages, their numbers could have been overlooked. This could also apply to predators such as Xanthandrus comtus (Syrphidae), the larvae of which prey on gregarious caterpillars (Rotheray \& Gilbert, 1999), including T. pityocampa (e.g. Biliotti, 1958). Two ant species, Formica fusca and Lasius sp. were observed in nests containing aphids, probably collecting honeydew, similarly to observed by Nakamura and Ohgushi (2003) for other types of shelters.

Novel data were obtained claryfing the role of T. pityocampa nests in Mediterranean pine ecosystems, a topic not addressed before. The indirect interactions documented, mainly with generalist predators, parasitoids, scavengers and fungi feeders, evidence the important functional role of $T$. pityocampa nests in pine ecosystem food webs. By contrast, only a negligible percentage of the arthropods using the caterpillars shelters were phytophagous, thus showing that nests do not promote direct interactions with other potential pests. Finally, a relevant link between habitat and insect conservation was identified, considering that arthropod diversity, sheltered in the nests, was positively correlated with understorey vegetation diversity.

Considering that defoliations of up to $25 \%$, caused by $T$. pityocampa, do not significantly affect the growth rate of Pinus pinaster (Barrento et al., 2008) and nests may contribute to biodiversity conservation, the present findings have practical implications regarding forest management strategies.

\section{Acknowledgments}

The authors are grateful to Dr. Jens Esser and Dr. Andreas Herrmann for providing information and identifying specimens of $M$. perrisii and D. aurichalceus, respectively; to Dr. Paula Seixas, M.Sc. Helena Santos, Marta Neves and Susana Almeida for field collection of T. pityocampa nests; to Dr. Zvi Mendel for valuable comments on an earlier draft of this paper. Finally, we thank Professor M. J. Way for pointing out the relevance of this work. The work was funded in part by EU project Promoth, QLRT-2001-00852.

\section{References}

Altieri, M.A. (1999) The ecological role of biodiversity in agroecosystems. Agriculture, Ecosystems and Environment, 74, 19-31.

Arevalo, D.P. (1992) Etude quantitative du parasitisme realise par Trichomalopsis peregrina dans les nids d'hiver d'Euproctis chrysorrhoea en chenaie. Entomophaga, 37, 239-247.

Barrento M.J., Santos H., Branco, M. \& Paiva, M.R. (2008) Monitorização da processionária do pinheiro, Thaumetopea pityocampa. Pragas e Doenças do Pinhal e Eucaliptal: Desafios Para a sua Gestão Integrada (ed. by M. Branco, C. Valente and M.R Paiva). ISA press, Lisbon, Portugal. In press.

Biliotti, E. (1958) Les parasites et prédateurs de Thaumetopoea pityocampa Schiff. (Lepidoptera). Entomophaga, 3, 23-24.

Bogya, S. \& Markó, V. (1999) Effect of pest management systems on ground dwelling spider assemblages in an apple orchard in Hungary. Agriculture, Ecosystems and Environment, 73, 7-18.

Bogya, S., Marko, V. \& Szinetar, C.S. (2000) Effect of pest management systems on foliage- and grass-dwelling spider communities in an apple orchard in Hungary, International Journal of Pest Management, 46, 241-250.

Bolker B., Holyoak M., Krivan V., Rowe L. \& Schmitz O. (2003) Connecting theoretical and empirical studies of trait-mediated interactions. Ecology, 84, 1101-1114.

Breuer, M. \& Devkota, B. (1990) Studies on the importance of nest temperature of Thaumetopoea pityocampa (Den. \& Schiff.) (Lep., Thaumetopoeidae). Journal of Applied Entomology, 109, 331-335.

Bryant, S.R., Thomas, C.D. \& Bale J.S. (2000) Thermal ecology of gregarious and solitary nettle-feeding nymphalid butterfly larvae. Oecologia, 122, 1432-1939.

Cappuccino, N. (1993) Mutual use of leaf-shelters by lepidopteran larvae on paper birch. Ecological Entomology, 18, 287-292.

Cappuccino, N. \& Martin, M.A. (1994) Eliminating early-season leaf-tiers of paper birch reduces abundance of mid-summer species. Ecological Entomology, 19, 399-401.

Costa, J.T. \& Pierce, N.E. (1997) Social evolution in the Lepidoptera, ecological context and communication in larval societies. The Evolution of Social Behavior in Insects and Arachnids (ed. by J.C. Choe and B.J. Crespi), pp. 407-442. Cambridge University Press, Cambridge, UK.

Fukui, A. (2001) Indirect interactions mediated by leaf shelters in animal-plant communities. Population Ecology, 43, 31-40.

Herrmann A. \& Bahillo de la Puebla, P. (2003) Sobre la presencia de Dermestes (Dermestinus) hankae Háva, 1999 y Dermestes (Dermestinus) aurichalceus Küster, 1846 (Coleoptera, Dermestidae) en la península Ibérica. Boletín de la SEA, 33, 91-93.

Hunter A.F. (1991) Trails that distinguish outbreaking and nonoutbreaking Macrolepidoptera feeding on northern hardwood trees. Oikos, 60, 275-282. 
Jones M.T., Castellanos, I. \& Weiss M.R. (2002) Do leaf shelters always protect caterpillars from invertebrate predators? Ecological Entomology, 27, 753-757.

Jones, G.C., Lawton, J.H. \& Shachak, M. (1994) Organisms as ecosystem engineers. Oikos, 69, 373-386.

Jones C.G., Lawton J.H. \& Shachak M. (1997) Positive and negative effects of organisms as physical ecosystem engineers. Ecology, 78, 1946-1957.

Kudo, S.I. (1994) Observations on lepidopteran leaf-shelters as molting refuges for the stink bug Elasmucha putoni (Heteroptera, Acanthosomatidae). Psyche, 101, 183-186.

Larsson S., Haggstrom H.E. \& Denno R. (1997) Preference for protected feeding sites by larvae of the willow-feeding leaf beetle Galerucella lineola. Ecological Entomology, 22, 445-452.

Lill, J.T. \& Marquis, R.J. (2004) Leaf ties as colonization sites for forest arthropods, an experimental. Ecological Entomology, 29, 300-308.

Marc, P., Canard, A. \&Ysnel, F. (1999) Spiders (Araneae) useful for pest limitation and bioindication. Agriculture, Ecosystems and Environment, 74, 229-273.

Martinsen, G.D., Floate, K.D., Waltz, A.M., Wimp, G.M. \& Whitham, T.G. (2000) Positive interactions between leafrollers and other arthropods enhance biodiversity on hybrid cottonwoods. Oecologia, 123, 82-89.

Nakamura, M. \& Ohgushi, T. (2003) Positive and negative effects of leaf shelters on herbivorous insects, linking multiple herbivore species on a willow. Oecologia, 136, 445-449.

Ohgushi, T. (2005) Indirect interaction webs: herbivore-induced indirect effects through trait change in plants. Annual Review of Ecology, Evolution and Systematics, 36, 81-105.

Otero, J.C. (2001) El género Micrambe C.G. Thomson, 1863 en la Península Ibérica e islas Baleares (Coleoptera, Cryptophagidae). Elytron, 15, 21-30.

Pérez-Contreras, T., Soler, J.J. \& Soler, M. (2003) Why do pine processionary caterpillars moth Thaumetopoea pityocampa (Lepidoptera, Thaumetopoeidae) live in large groups? Annales Zoologici Fennici, 40, 505-515.

Reska, M. (1994) Bestimmungstabellen der mitteleuropäischen Arten der Gattungen Micrambe Thomson und Cryptophagus Herbst (Insecta,
Coleoptera, Cryptophagidae). Annalen des Naturhistorischen Museums in Wien, 96B, 247-342.

Rotheray, G.E. \& Gilbert, F. (1999) Phylogeny of Palaearctic Syrphidae (Diptera), evidence from larval stages. Zoological Journal of the Linnean Society, 127, 1-112.

Ruf, C. \& Fiedler K. (2000) Thermal gains through collective metabolic heat production in social caterpillars of Eriogaster lanestris. Naturwissenschaften, 87, 193-196.

Ruf, C. \& Fiedler, K. (2002) Tent-based thermoregulation in social caterpillars of Eriogaster lanestris (Lepidoptera, Lasiocampidae), behavioral mechanisms and physical features of the tent. Journal of Thermal Biology, 27, 493-501.

Santos, H., Branco, M., Moura, E. \& Paiva, M.R. (2002) Comparação da biodiversidade de himenópteros em dois povoamentos de Pinus pinaster Ait. Revista de Biologia, 19, 71-86.

Schmitz, O.J. \& Suttle, B.K. (2001) Effects of top predator species on direct and indirect interactions in a food web. Ecology, 82, 20722081.

Siemann, E. (1998) Experimental tests of effects of plant productivity and diversity on grassland arthropod diversity. Ecology, 79, 20572070.

Sneath, P.H.A. \& Sokal, R.R. (1973) Numerical Taxonomy. W. H. Freeman, San Francisco.

Triggiani, O., Lillo, E. \& Addante, R. (1993) La procesionaria del pino, Thaumetopoea pityocampa (Den. et Schiff.) (Lepidoptera, Thaumetopoeidae), e i suoi nemici naturali in puglia. Entomologica, 27, 139167.

Uetz, G.W., Halaj J. \& Alan, B.C. (1999) Guild structure of spiders in major crops. The Journal of Arachnology, 27, 270-280.

Weiss, M.R., Wilson, E.E. \& Castellanos, I. (2004) Predatory wasps learn to overcome the shelter defences of their larval prey. Animal Behaviour, 68, 45-54.

Werner, E.E. \& Peacor, S.D. (2003) A review of trait-mediated indirect interactions in ecological communities. Ecology, 84, 1083-1100.

Accepted 25 August 2008

Editor: Simon R. Leather

Associate editor: Robert Ewers 
Copyright of Insect Conservation \& Diversity is the property of Blackwell Publishing Limited and its content may not be copied or emailed to multiple sites or posted to a listserv without the copyright holder's express written permission. However, users may print, download, or email articles for individual use. 